\title{
A Scoping Review of Different Methods of Assessing the Impact of New Medical Technologies at Early Stages of Development
}

\author{
Zahra Goudarzi ${ }^{1,2}$, Shekoufeh Nikfar ${ }^{1}$, Abbas Kebriaeezadeh $^{3}$, Reza Yousefi Zenouz ${ }^{4}$, Akbar Abdollahi Asl $^{3} * \mathbb{D}$, \\ Nader Tavakoli ${ }^{5}$
}

Received: 27 Jan 2020

Published: 26 Oct 2021

Abstract

Background: Investing in the R\&D sector of new medical technologies is associated with the risk of being rejected by paying organizations because of the lack of value-for-money. The purpose of this study is to investigate the different methods of evaluating the impacts of emerging medical technologies.

Methods: Using scoping review method, we analyzed studies that investigated methods for assesising the impacts of emerging medical technologies on development. To find these studies, the Cochran Library, ISI Web of Knowledge, Embase, Ebsco and Pubmed databases from 2000 to 2018 were searched. The methodological quality of the studies was assessed using the STROBE Checklist. Two reviewers independently selected the qualified studies. Charting and collating the data were used based on the method proposed by Arksey and O'Malley.

Results: Overall, 38 studies met the inclusion criteria. Sixteen methods were identified and put in five distinct categories: forecasting, Pro-HTA, Early-HTA, priority setting, and HHS were found to measure the impact of emerging technologies. The quality of these studies was acceptable. Few studies were conducted on emerging pharmaceutical technologies, and they were mostly on emerging medical devices. The Early HTA methods were often used to measure the effects of pharmaceutical technologies and medical devices technologies. The Pro-HTA method used dynamic modeling to examine the impact of medical technologies on a broad range of dimensions, while the HTA and Early-HTA methods used cost-effectiveness techniques throughout the development process. The HHS method used a multivariate decision-making technique.

Conclusion: Different methods were used to investigate the impacts of emerging medical technologies. Chronologically Pro-HTA methods are new ways for investigating emerging medical technologies beyond clinical and economic impacts. Assessing the feasibility of implementing Pro-HTA in real environments deserves further research.

Keywords: Early Stages of Technology Development, New Medical Technologies, Health Technology Assessment, Emerging Pharmaceuticals

Conflicts of Interest: None declared

Funding: None

\section{*This work has been published under CC BY-NC-SA 1.0 license.}

Copyright $\odot$ Iran University of Medical Sciences

Cite this article as: Goudarzi Z, Nikfar Sh, Kebriaeezadeh A, Yousefi Zenouz R, Abdollahi Asl A, Tavakoli N. A Scoping Review of Different Methods of Assessing the Impact of New Medical Technologies at Early Stages of Development. Med J Islam Repub Iran. 2021 (26 Oct);35:141. https://doi.org/10.47176/mjiri.35.141

\section{Introduction}

Medical Technological advances threaten financial sus- tainability in many health care systems; thus the efficient
Corresponding author: Dr Akbar Abdollahi Asl, abdollahiasl@gmail.com

${ }^{1 .}$ Department of Pharmacoeconomics and Pharmaceutical Administration, Faculty of Pharmacy, Tehran University of Medical Sciences, Tehran, Iran

${ }^{2 .}$ Health Human Resources Research Centre, School of Management and Medical Informatics, Shiraz University of Medical Sciences, Shiraz, Iran

3. Department of Pharmacoeconomics and Pharmaceutical Management, Faculty of Pharmacy, Tehran University of Medical sciences, Tehran, Iran

4. Department of Operations and Information Technology Management, Faculty of Management, Kharazmi University, Tehran, Iran

5. Trauma and Injury Research Center, Iran University of Medical Sciences, Tehran, Iran $\uparrow$ What is "already known” in this topic:

Classical Health Technology Assessment (HTA) is commonly used in the evaluation of medical technologies with sufficient available evidence. But some approaches are increasingly being, used to support health economic evidence development during the early stages of technology development.

\section{$\rightarrow$ What this article adds:}

Sixteen methods were identified that investigated the impacts of emerging medical technologies. Chronologically Pro-HTA is a new method using a dynamic simulation approach for investigating emerging medical technologies beyond clinical and economic impacts. Assessing the feasibility of implementing Pro-HTA in real environments deserves further research. 
and optimal allocation of resources are important challenges for the system (1). One of the ways to manage the consequence of technological pressure involves the presence of a health care system in charge of emerging technologies as soon as possible before the product is fully developed. The health care system would track emerging technologies and try to invest in products that are potentially cost-effective in addition to their significant clinical benefit (2).

Emerging medical technologies are always accompanied by uncertainty. On the one hand, the emergence of medical technologies leads to the expansion of national wealth, increased competitiveness, increased exports, and increased welfare and quality of life .On the other hand, it can lead to problems such as increased induced demand, increased medical costs without necessary efficacy, increased patients' life span with poor quality of life $(3,4)$. So it is important to assess the clinical and economic consequences of emerging technologies. Common approaches, such as health technology assessment (HTA) reports, have not helped policymakers much in selecting and evaluating technologies (5).

Over the past two decades, the use of product assessment models in their early stages of development has been of interest to provide timely information for the ongoing process of development, market access, and technology pricing. The primary purpose of this study was to undertake a comprehensive review of the literature in the early stages of development to identify methods of a technology evaluation. The second purpose is to identify new methods to assess the potential impact of emerging medical technologies.

\section{Methods \\ Study Design}

This scoping review was conducted to identify different methods of evaluating emerging medical technologies in their early stages of development. We followed the methodology proposed by Arksey and O'Malley in five steps (6).

\section{Stage1, Research question and eligibility criteria}

The research question concerns the current methods to evaluate potential impacts of new medical technologies in terms of clinical and economic consequences in the early stage of development to make a better decision regarding the governance of these technologies?

Inclusion criteria were all studies evaluating medical technologies at various stages of development before entering the market, such as seminal research, laboratory phase, animal phase, clinical phase, and pre-market launch. Medical technologies include those emerging health technologies used directly to diagnose or treat a health condition, e.g., medicines, medical devices, diagnostic tests or medical equipment.

\section{Stage 2, Identifying relevant studies}

The studies included a broad category of study designs to capture comprehensiveness. We included surveys, cross-sectional, descriptive, qualitative, national, and in- ternational reports, systematic reviews, and discussion studies. PubMed, Cochrane Library (through own website), ISI Web of knowledge, and Embase (through the Ovid website) from 2000 to 2018 were electronically searched to find potential eligible studies. We also tracked references of marker studies, the website of related organizations and conferences to find more relevant studies. Moreover, the studies presented in International Society for Pharmaceutical and Outcome Research (ISPOR) conferences (up to 2018) were also searched.

According to the study question and having reviewed the studies, the search strategies were written according to the guidelines of each database. Details for search strategies in two databases and retrieved records are available in a Appendix. The basic search strategies are as follows:

1- Model (Title/Abstract) OR tool (Title/Abstract) OR Simulation (Title/Abstract) OR forecast(Title/Abstract) OR foresight (Title/Abstract) OR (Title/Abstract) future foresight process (Title/Abstract) OR technology foresight (Title/Abstract) OR health technology assessment (Title/Abstract) OR horizon scanning (Title/Abstract) OR prospective simulation (Title/Abstract) OR Pro HTA (Title/Abstract) OR dynamic model (Title/Abstract) OR prospective assessment (Title/Abstract)

2- Pharmaceutical innovation (Title/Abstract) OR Pharmaceutical diffusion (Title/Abstract) OR health technology diffusion (Title/Abstract) OR Emerging innovation (Title/Abstract) OR emerging drug (Title/Abstract) OR new drug (Title/Abstract) OR new medicine (Title/Abstract) OR drug entity (Title/Abstract) OR medicine entity (Title/Abstract) OR emerging health technology (Title/Abstract) OR healthcare innovation (Title/Abstract) OR medical device (Title/Abstract)

\section{3- \#1 AND \#2}

\section{Stage 3, Study selection}

We followed the PRISMA guidelines to find relevant studies. We included studies with methods to assess the impacts of emerging technologies on the health care system, such as new pharmaceutical and medical devices. Studies that had at least an English abstract were included in the evaluation. The results of the selected databases were entered into the Endnote Software (X.9.33 version). After removing duplicate studlies, the titles and abstracts were studied. After unrelated studies were removed, the full texts of the remaining studies were reviewed. Two authors individually performed the above steps . They also independently assessed the quality of the studies included using the STROBE checklist.

\section{Stage 4, Charting the data}

A datasheet was then used to extract the data .Data were extracted independently by two individuals. The information extracted included authors' names, year of publication, country of study, dimensions, and variables influencing the access to emerging technologies, evaluation methods, and techniques, and studies' title, language, perspective, and outcome index. 
Stage 5, Collating, summarizing, and reporting the result

This stage of a scoping study involves collating, summarizing and reporting the results. At first, we summarized the main characteristics of the studies such as year of publication, country of origin, type of method used to assess an emerging technology in the early stage of development, quantitative or qualitative algorithms to assess, criteria used to make decisions and perspective of the studies. We also divided the studies according to the type of emerging technologies. Then, the included studies were counted and ordered chronologically in terms of the types of medical technologies. A clear distinction was made between identified methods and comparative analysis of included studies based on the main characteristics.

\section{Results}

This study which was a scoping review, included 10,578 records in total and 8 studies that were added manually. A total of 3,275 studies were excluded after duplicate records were excluded and 7,303 records remained for assessment.

After reviewing the titles/abstracts, 319 abstracts remained. Among them, 58 records were eligible after reading the full text, but 21 studies were excluded as they were not original, lacked data sufficiency or the full text, or were not related to the health system. Finally, 38 records met the inclusion/exclusion criteria (Fig. 1).

Most of the studies were conducted in the Netherlands (13 studies), Germany (6 studies), and UK (6 studies) and the other conducted in Belgium (2 studies), Switzerland (2 studies), Denmark (3 studies), Sweden (3 studies), United States (3 studies), New Zeeland (1 study) and Korea (1 study). Among these, 23 studies focused on medical equipment and diagnostic tests, 7 studies on pharmaceuticals and 8 studies were related to all new technologies and not specifically to a distinct category of medical technologies. Table 1 provides more detailed information about the studies.

Five general approaches to evaluate new technologies were identified at an early stage of development. Overall, 27 studies evaluated technologies using the early HTA approach, 4 studies using the pro-HTA method, 2 studies using horizon scanning, 3 studies using priority-setting techniques, and 3 studies using forecasting methods. Figure 2 shows these studies based on the time of the study and the type of intervention. The figure shows that in recent years most of the researchers used the early HTA approach to assess the effectiveness of emerging medical technologies.

\section{Methods used in evaluating emerging technologies}

1- Early health technology assessment: This approach is often undertaken in the context of economic evaluation studies in combination with clinical trial development strategies. The main purpose of this model is to evaluate the cost and effectiveness of interventions in the early stages of development. The first study using this approach was published in 1993 by Clemens, et al. (7). A review of the literature from 1993 to 2006 shows that this approach has often been used in the evaluation of emerging drugs in stages 1 and 2 of clinical trials, suggesting an uncertainty of evidence in a clinical trial or suggestions to improve or stop further trials (7-11). Dong, Van Til, and Hjelmgren reported the results of medicall device evaluation (12-14).

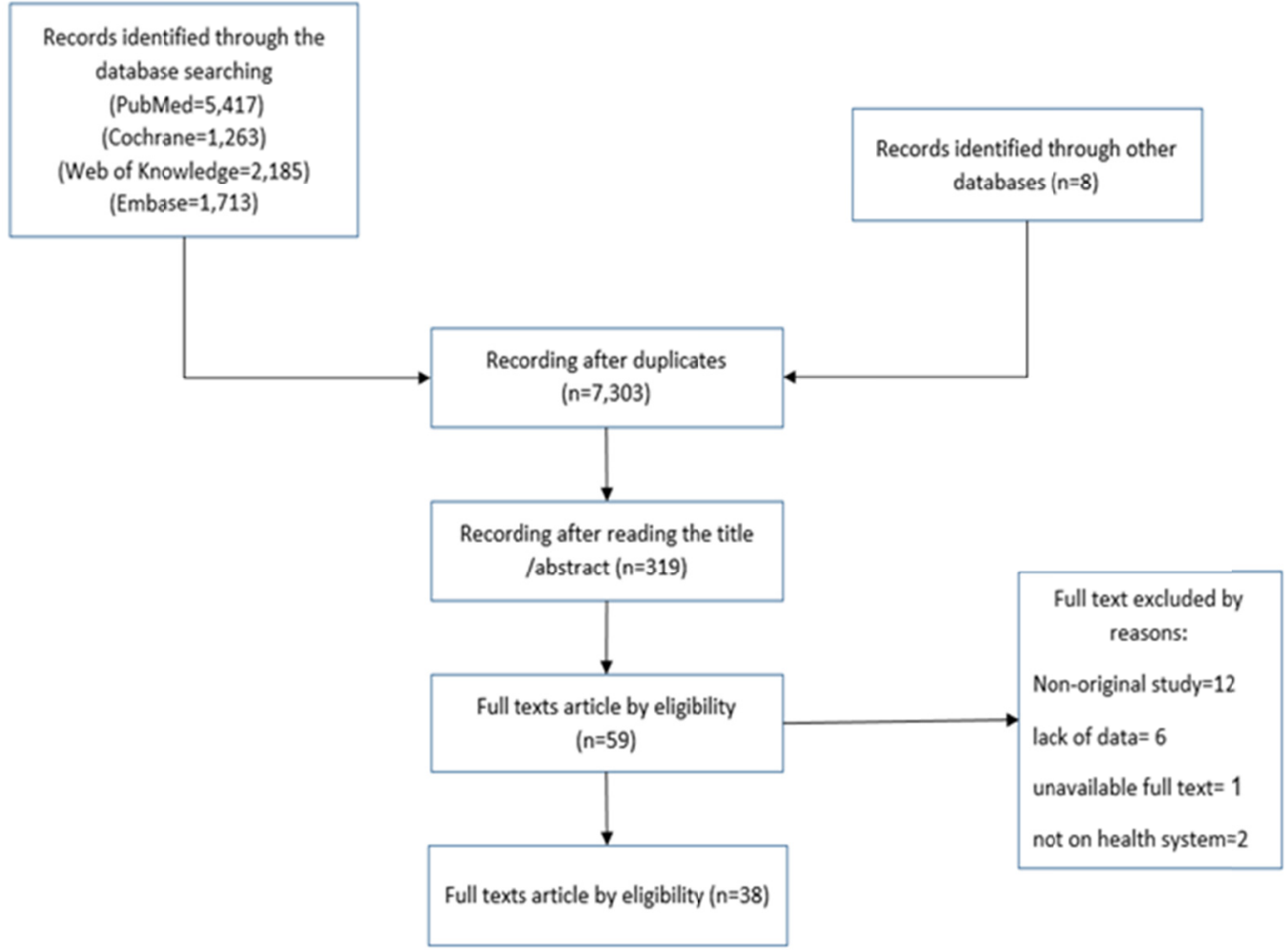

Fig. 1. PRISMA flowchart to find included studies 
Table 1. Characteristics of included studies

\begin{tabular}{|c|c|c|c|c|c|c|c|c|}
\hline Authors & $\begin{array}{c}\text { Published } \\
\text { year }\end{array}$ & Country & Intervention & R \&D stage & Method & $\begin{array}{c}\text { Technique of } \\
\text { modeling }\end{array}$ & Perspective & Type of study \\
\hline Kirsten J.M (31) & 2017 & USA & Diagnostic trajectory & Before trial & $\begin{array}{l}\text { Early } \\
\text { HTA }\end{array}$ & $\begin{array}{c}\text { Headroom } \\
\text { analysis }\end{array}$ & Stockholder & $\begin{array}{c}\text { Observational } \\
\text { study }\end{array}$ \\
\hline $\begin{array}{l}\text { Aris Angelis } \\
\text { (32) }\end{array}$ & 2017 & UK & $\begin{array}{l}\text { Medicines, medical } \\
\text { devices and other } \\
\text { health interventions }\end{array}$ & Market launch & $\begin{array}{l}\text { Context } \\
\text { of HTA }\end{array}$ & MCDA & Decision maker & Qualitative \\
\hline $\begin{array}{l}\text { Kolominsky } \\
\text { Rabas (5) }\end{array}$ & 2016 & Germany & $\begin{array}{c}\text { Device } \\
\text { (Mobile Stroke Units) }\end{array}$ & Pre trial & Pro-HTA & $\begin{array}{c}\text { System } \\
\text { Dynamics } \\
\text { and agent } \\
\text { base model }\end{array}$ & Decision maker & Descriptive \\
\hline $\begin{array}{l}\text { Aastha Gupta } \\
\text { (33) }\end{array}$ & 2016 & Switzerland & $\begin{array}{l}\text { Medicine (anti- } \\
\text { retroviral treatment } \\
\text { (ART)) }\end{array}$ & Pre market & $\begin{array}{l}\text { Forecast } \\
\text { Analysis }\end{array}$ & $\begin{array}{l}\text { Predict } \\
\text { market } \\
\text { shares }\end{array}$ & Decision maker & Descriptive \\
\hline $\begin{array}{l}\text { Katarzyna } \\
\text { Markiewicz (27) }\end{array}$ & 2016 & Netherlands & Device & & $\begin{array}{l}\text { Early } \\
\text { HTA }\end{array}$ & $\begin{array}{c}\text { Headroom } \\
\text { analysis \& } \\
\text { ROI analysis }\end{array}$ & Manufacturers & Case study \\
\hline $\begin{array}{l}\text { Michelle MA } \\
\text { Kip (34) }\end{array}$ & 2016 & Netherlands & $\begin{array}{l}\text { triple biomarker test } \\
\text { (copeptin, heart-type } \\
\text { fatty acid binding } \\
\text { protein, and high- } \\
\text { sensitivity troponin } \\
(\text { HsTn)) }\end{array}$ & $\begin{array}{c}\text { Technology } \\
\text { available but } \\
\text { not used }\end{array}$ & $\begin{array}{l}\text { Early } \\
\text { HTA }\end{array}$ & $\begin{array}{c}\text { Decision tree } \\
\$ \text { expert } \\
\text { elicitation }\end{array}$ & Societal & $\begin{array}{c}\text { Observational } \\
\text { study }\end{array}$ \\
\hline $\begin{array}{l}\text { Middelkamp } \\
\text { H.H (35) }\end{array}$ & 2016 & Netherlands & $\begin{array}{l}\text { Device (Organs-on- } \\
\text { Chips) }\end{array}$ & $\begin{array}{l}\text { Early stage of } \\
\text { development }\end{array}$ & $\begin{array}{l}\text { Early } \\
\text { HTA }\end{array}$ & MCDA & Stockholders & $\begin{array}{c}\text { Observational } \\
\text { study }\end{array}$ \\
\hline $\begin{array}{l}\text { Isabel Püntmann } \\
\text { (36) }\end{array}$ & 2010 & Germany & Medicine & $\begin{array}{l}\text { Early stage } \\
\text { clinical } \\
\text { research }\end{array}$ & $\begin{array}{l}\text { Early } \\
\text { HTA }\end{array}$ & EVITA & $\begin{array}{c}\text { Physicians and } \\
\text { other professionals }\end{array}$ & Descriptive \\
\hline Jilles (37) & 2016 & Netherlands & $\begin{array}{l}\text { Forty-one technologies } \\
\text { (16 pharmaceuticals } \\
\text { and } 25 \text { non- } \\
\text { pharmaceuticals) were }\end{array}$ & Premarket & $\begin{array}{l}\text { Priority } \\
\text { setting }\end{array}$ & $\begin{array}{l}\text { Best-worst } \\
\text { scaling }\end{array}$ & Stockholders & Descriptive \\
\hline Joosten SE (38) & 2016 & Netherlands & $\begin{array}{l}\text { NGS-based molecular } \\
\text { diagnostics }\end{array}$ & Pre clinical & $\begin{array}{l}\text { Early } \\
\text { HTA }\end{array}$ & $\begin{array}{l}\text { Scenario } \\
\text { drafting, } \\
\text { expert elici- } \\
\text { tation }\end{array}$ & Stockholder & $\begin{array}{c}\text { Observational } \\
\text { study }\end{array}$ \\
\hline $\begin{array}{l}\text { Huygens SA } \\
\text { (39) }\end{array}$ & 2016 & UK & $\begin{array}{l}\text { Device (tissue- } \\
\text { engineered heart } \\
\text { valves) }\end{array}$ & $\begin{array}{l}\text { Early stage } \\
\text { clinical } \\
\text { research, }\end{array}$ & $\begin{array}{l}\text { Early } \\
\text { HTA }\end{array}$ & $\begin{array}{l}\text { Delphi panel } \\
\text { with experts }\end{array}$ & Societal & \\
\hline $\begin{array}{l}\text { Alan Girling } \\
\text { (40) }\end{array}$ & 2015 & UK & Device & $\begin{array}{l}\text { Early stage } \\
\text { clinical } \\
\text { research }\end{array}$ & $\begin{array}{l}\text { Early } \\
\text { HTA }\end{array}$ & $\begin{array}{l}\text { Headroom } \\
\text { analysis }\end{array}$ & Manufacturers & Descriptive \\
\hline Tommy S (41) & 2015 & Netherlands & $\begin{array}{l}\text { Instant MSC Product } \\
\text { accompanying } \\
\text { Autologous Chondron } \\
\text { Transplantation }\end{array}$ & $\begin{array}{l}\text { Early stage } \\
\text { clinical } \\
\text { research, tests } \\
\text { are available }\end{array}$ & $\begin{array}{l}\text { Early } \\
\text { HTA }\end{array}$ & $\begin{array}{l}\text { Markov } \\
\text { model, } \\
\text { headroom } \\
\text { analysis }\end{array}$ & Societal & $\begin{array}{c}\text { Observational } \\
\text { study }\end{array}$ \\
\hline Georg Ruile (42) & 2015 & Germany & $\begin{array}{l}\text { Computed tomography } \\
\text { (CT) system }\end{array}$ & $\begin{array}{l}\text { Early stage of } \\
\text { trial }\end{array}$ & $\begin{array}{l}\text { PRO- } \\
\text { HTA }\end{array}$ & $\begin{array}{l}\text { Simulation } \\
\text { with scenario } \\
\text { drafting }\end{array}$ & Society & $\begin{array}{c}\text { Observational } \\
\text { study }\end{array}$ \\
\hline $\begin{array}{l}\text { Kolominsky } \\
\text { Rabas (15) }\end{array}$ & 2014 & Germany & $\begin{array}{l}\text { Sensor for managing } \\
\text { pulmonary artery in } \\
\text { heart failure patients }\end{array}$ & $\begin{array}{l}\text { Implementa- } \\
\text { tion } \\
\text { of a new } \\
\text { device } \\
\text { to guide health } \\
\text { services } \\
\text { planning }\end{array}$ & Pro-HTA & $\begin{array}{l}\text { System } \\
\text { dynamic }\end{array}$ & Societal & $\begin{array}{c}\text { Observational } \\
\text { study }\end{array}$ \\
\hline $\begin{array}{l}\text { Wieke Haakma } \\
\text { (43) }\end{array}$ & 2014 & Switzerland & $\begin{array}{c}\text { Photoacoustic mam- } \\
\text { mography } \\
\text { (PAM) imaging } \\
\text { for detecting breast } \\
\text { cancer }\end{array}$ & $\begin{array}{c}\text { Early stage of } \\
\text { development }\end{array}$ & $\begin{array}{l}\text { Early } \\
\text { HTA }\end{array}$ & $\begin{array}{l}\text { Expert } \\
\text { elicitation }\end{array}$ & Decision maker & $\begin{array}{c}\text { Observational } \\
\text { study }\end{array}$ \\
\hline $\begin{array}{l}\text { Marion Gantner } \\
\text { (23) }\end{array}$ & 2014 & Germany & $\begin{array}{c}\text { Prostate specific } \\
\text { antigen test }\end{array}$ & $\begin{array}{l}\text { Early research } \\
\text { and concept } \\
\text { phase of an } \\
\text { idea and } \\
\text { before major } \\
\text { investments } \\
\text { are made. }\end{array}$ & $\begin{array}{l}\text { Early } \\
\text { HTA }\end{array}$ & EVITA & Stockholders & Descriptive \\
\hline $\begin{array}{l}\text { Bengt Jonsson } \\
\text { (44) }\end{array}$ & 2014 & Sweden & $\begin{array}{l}\text { Medicine (ipilimumab } \\
\text { for the treatment of } \\
\text { metastatic melanoma) }\end{array}$ & $\begin{array}{l}\text { Early devel- } \\
\text { opment phases }\end{array}$ & $\begin{array}{l}\text { Early } \\
\text { HTA }\end{array}$ & $\begin{array}{c}\text { Markov } \\
\text { model }\end{array}$ & Decision maker & Descriptive \\
\hline
\end{tabular}

This means the beginning of a new paradigm in the early HTA strategy, which provides adequate knowledge along with reimbursement and regulatory approaches for consumers and suppliers through the incorporation of the health system and industry perspectives. Based on the study results, this method uses various techniques to test technologies which are briefly listed in Table 2 .
2- Pro-HTA: The primary purpose of pro-HTA is to evaluate emerging medical technologies from the perspective of health systems and technology makers. By simulating the potential impacts of new technologies, this model identifies the potentials and shortcomings of these technologies in the health system and seeks to predict the potential of the product in the future market. The main dif-

\footnotetext{
4 http://mjiri.iums.ac.ir 


\begin{tabular}{|c|c|c|c|c|c|c|c|c|}
\hline Authors & $\begin{array}{c}\text { Published } \\
\text { year }\end{array}$ & Country & Intervention & R \&D stage & Method & $\begin{array}{l}\text { Technique of model- } \\
\text { ing }\end{array}$ & Perspective & Type of study \\
\hline Qi Cao (45) & 2013 & Netherlands & $\begin{array}{l}\text { Device (point-of- } \\
\text { care testing } \\
\text { (POCT)) }\end{array}$ & Market launch & $\begin{array}{l}\text { Early } \\
\text { HTA }\end{array}$ & $\begin{array}{l}\text { Headroom analysis, } \\
\text { Markov model, ex- } \\
\text { pert elicitation }\end{array}$ & Stockholders & Case study \\
\hline $\begin{array}{l}\text { Anatoli Djanat- } \\
\text { liev (22) }\end{array}$ & 2013 & Germany & $\begin{array}{l}\text { Markers for Prostate } \\
\text { Cancer Screening \& } \\
\text { Mobile Stroke Units }\end{array}$ & $\begin{array}{c}\text { Before the } \\
\text { design and devel- } \\
\text { opment phase has } \\
\text { started }\end{array}$ & Pro HTA & $\begin{array}{l}\text { System Dynamics } \\
\text { and Agent-Based }\end{array}$ & Decision maker & Descriptive \\
\hline $\begin{array}{l}\text { Valesca P. Retèl } \\
\text { (46) }\end{array}$ & 2013 & Netherlands & $\begin{array}{c}\text { (70G-FFT), (70G- } \\
\text { PAR) }\end{array}$ & $\begin{array}{c}\text { Early stages of } \\
\text { development }\end{array}$ & $\begin{array}{l}\text { early } \\
\text { HTA }\end{array}$ & Markov model & Societal & Descriptive \\
\hline $\begin{array}{l}\text { Wim H van } \\
\text { Harten }(26)\end{array}$ & 2012 & Netherlands & $\begin{array}{l}\text { 70-gene signature } \\
\text { for breast cancer }\end{array}$ & $\begin{array}{l}\text { Early stages of } \\
\text { promising new } \\
\text { technologies }\end{array}$ & $\begin{array}{l}\text { Early } \\
\text { HTA }\end{array}$ & Scenario analyzing & Stockholders & \\
\hline $\begin{array}{l}\text { Douwe Postmus } \\
\text { (47) }\end{array}$ & 2011 & Netherlands & $\begin{array}{l}\text { A novel biomarker } \\
\text { technology for } \\
\text { identifying individ- } \\
\text { uals at } \\
\text { risk of developing a } \\
\text { chronic disease }\end{array}$ & $\begin{array}{l}\text { Early stages of } \\
\text { promising new } \\
\text { technologies }\end{array}$ & $\begin{array}{l}\text { Early } \\
\text { HTA }\end{array}$ & Markov & Industry & Cohort study \\
\hline Ofra Golana (48) & 2010 & New Zealand & Medicine or device & $\begin{array}{l}\text { Technology } \\
\text { available but } \\
\text { not used }\end{array}$ & $\begin{array}{l}\text { Priority } \\
\text { setting }\end{array}$ & Conjoint-analysis & Decision maker & Qualitative \\
\hline Pietzsch JB (49) & 2008 & USA & Device & $\begin{array}{l}\text { Early stage of } \\
\text { development }\end{array}$ & $\begin{array}{l}\text { Early } \\
\text { HTA }\end{array}$ & $\begin{array}{l}\text { engineering risk } \\
\text { analysis }\end{array}$ & Industry & Descriptive \\
\hline Emma Cosh (50) & 2007 & UK & Technology & $\begin{array}{l}\text { As early as possi- } \\
\text { ble } \\
\text { in the develop- } \\
\text { ment cycle }\end{array}$ & $\begin{array}{l}\text { Early } \\
\text { HTA }\end{array}$ & $\begin{array}{l}\text { Headroom analysis, } \\
\text { and } \\
\text { revenue analysis }\end{array}$ & Industry & Descriptive \\
\hline $\begin{array}{l}\text { Filip Mussen } \\
\text { (51) }\end{array}$ & 2007 & Belgium & Medicine & Market launch & $\begin{array}{l}\text { Early } \\
\text { HTA }\end{array}$ & MCDA & Decision maker & Descriptive \\
\hline $\begin{array}{l}\text { Hengjin Dong } \\
(52)\end{array}$ & 2006 & UK & $\begin{array}{l}\text { Knee replacement } \\
\text { (TKR) using com- } \\
\text { puter-assisted } \\
\text { surgery }\end{array}$ & $\begin{array}{l}\text { Early in the life- } \\
\text { cycle of new } \\
\text { technologies }\end{array}$ & $\begin{array}{l}\text { Early } \\
\text { HTA }\end{array}$ & Markov model & Decision maker & Descriptive \\
\hline Karla Douw (53) & 2006 & Denmark & $\begin{array}{l}\text { Medicine or no } \\
\text { medicine }\end{array}$ & $\begin{array}{l}\text { Early stage of } \\
\text { clinical trial (1-2- } \\
3)\end{array}$ & $\begin{array}{l}\text { Horizon } \\
\text { scanning } \\
\text { systems }\end{array}$ & Delphi panels & Decision maker & Descriptive \\
\hline Karla Douw (54) & 2006 & Denmark & Device & $1,2,3$ clinical trial & $\begin{array}{l}\text { Horizon } \\
\text { scanning }\end{array}$ & MCDA & Societal & Qualitative \\
\hline Van Til JA (55) & 2006 & Netherlands & $\begin{array}{c}\text { Percutaneously } \\
\text { neuromuscular } \\
\text { electrical stimula- } \\
\text { tion }\end{array}$ & Stage II trial & $\begin{array}{l}\text { Early } \\
\text { HTA }\end{array}$ & - & Society & Clinical Trial \\
\hline $\begin{array}{l}\text { Jonas Hjelmgren } \\
\text { (56) }\end{array}$ & 2006 & Sweden & $\begin{array}{c}\text { Cell } \\
\text { replacement therapy } \\
\text { in Parkinson's } \\
\text { disease }\end{array}$ & Early stage in trial & $\begin{array}{l}\text { Early } \\
\text { HTA }\end{array}$ & - & Decision maker & $\begin{array}{c}\text { Observational } \\
\text { study }\end{array}$ \\
\hline Paul Miller (57) & 2005 & Sweden & Medicine & $\begin{array}{l}\text { Early develop- } \\
\text { ment phases }\end{array}$ & $\begin{array}{l}\text { Early } \\
\text { HTA }\end{array}$ & $\begin{array}{c}\text { Clinical } \\
\text { trial simulation, } \\
\text { option pricing, } \\
\text { investment appraisal } \\
\text {, threshold } \\
\text { analysis, and value } \\
\text { of information } \\
\text { (analysis }\end{array}$ & Stockholders & $\begin{array}{c}\text { Observational } \\
\text { study }\end{array}$ \\
\hline $\begin{array}{l}\text { Robert Phaal } \\
(58)\end{array}$ & 2004 & UK & Every technology & $\begin{array}{c}\text { Early stage of } \\
\text { development }\end{array}$ & $\begin{array}{l}\text { Forecast- } \\
\text { ing }\end{array}$ & Road mapping & $\begin{array}{l}\text { Industry, } \\
\text { multiorganaza- } \\
\text { tional }\end{array}$ & Descriptive \\
\hline Karla Douw (59) & 2004 & Denmark & $\begin{array}{l}\text { Medicine or no } \\
\text { medicine }\end{array}$ & $\begin{array}{l}\text { Early stage of } \\
\text { development }\end{array}$ & $\begin{array}{l}\text { Early } \\
\text { HTA }\end{array}$ & Clinical experts & Decision maker & Descriptive \\
\hline $\begin{array}{l}\text { Jeong-Dong } \\
\text { LeeT (60) }\end{array}$ & 2003 & Korea & $\begin{array}{l}\text { Multigenerational } \\
\text { product }\end{array}$ & & $\begin{array}{l}\text { Forecast- } \\
\quad \text { ing }\end{array}$ & $\begin{array}{l}\text { Time-series analysis } \\
\& \text { discrete choice } \\
\text { models }\end{array}$ & Consumer & Descriptive \\
\hline Joseph A (61) & 2001 & USA & Medicine & $\begin{array}{l}\text { Early develop- } \\
\text { ment phases }\end{array}$ & $\begin{array}{l}\text { Early } \\
\text { HTA }\end{array}$ & discrete & Stockholders & Descriptive \\
\hline $\begin{array}{l}\text { Lieven Anne- } \\
\text { mans (62) }\end{array}$ & 2000 & Belgium & Medicine & $\begin{array}{l}\text { Early develop- } \\
\text { ment phases }\end{array}$ & $\begin{array}{l}\text { Early } \\
\text { HTA }\end{array}$ & - & - & Descriptive \\
\hline
\end{tabular}

ference between this approach with early HTA and horizon scanning is that by simulating the system, it explores the potential benefits and disadvantages of using preproduct technology. In fact, by integrating technologies and processes into simulation scenarios, it depicts the effects of technologies on stakeholders, processes, and reimbursements throughout the system (15).

3- Horizon scanning: Horizon scanning studies are part of a broader field of health technology assessment. By determining priorities and the most important technologies for evaluation, and ultimately the evaluation of treatments among the selected technologies, provides health policymakers with the information needed to make decisions. Initial evaluation includes information such as aspects of safety, effectiveness, and financial, organizational, ethical, and other factors related to the anticipation of new technology releases.

The main difference between health technology assessment and the horizon scanning system is that the latter focuses mainly on evaluating and prioritizing new products at different stages of their fabrication, while health technology assessment studies focus on evaluating newly 


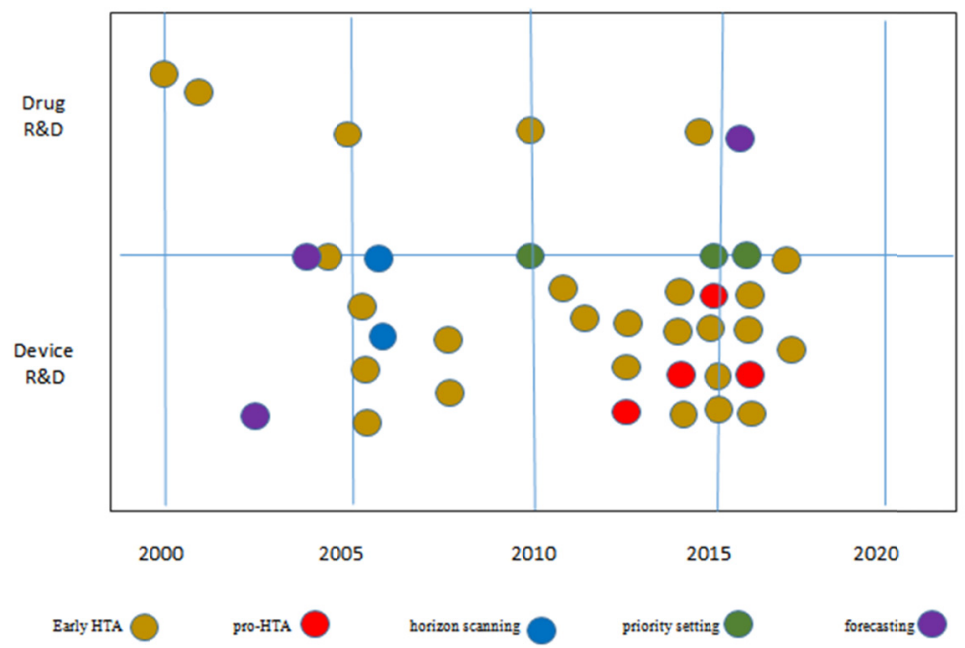

Fig. 2. Review studies presenting iterative economic evaluation in drug and medical device development, based on technology evaluation methods

made technologies. The general steps of this approach include 1. Identification: identification of emerging pharmaceutical and non-pharmaceutical technologies. 2. Filtering: Selecting the most important and most efficient technologies from the experts' point of view. 3. Priority setting: Prioritize these technologies based on different evaluation criteria from the perspective of each country. 4 . Assessment: using evaluation methods for comparing two drugs or interventions in two different therapies (16).

4- Priority setting: Given the accelerating development of technology and the increasing demand for services as well as resource limitations, the past decade has experienced the increasing use of rational and transparent approaches in service prioritization (17). Therefore, this method identifies a wide range of accessible services by prioritizing services according to some specific criteria, including demographic factors, epidemiology, infrastructure, reimbursement mechanisms, costs, and potential benefits of service utilization. As mentioned earlier, this technique is one of the HSS (Horizon Scanning System) steps, but some studies have used it separately to evaluate technologies (18).

Table 2. Various techniques are used in different approachs to evaluate technologies

\begin{tabular}{|c|c|c|c|}
\hline Modelling & Technic & Definition & Study \\
\hline \multirow{8}{*}{ Early HTA } & EVITA $^{1}$ & $\begin{array}{l}\text { An algorithm for initial evaluation of risk and benefit of new } \\
\text { drugs. In this approach, the benefits of pharmaceutical treatment } \\
\text { are calculated by: (1) the purpose of treatment; (2) disease catego- } \\
\text { ry; (3) trial setting; and (4) the average score of risk and benefits } \\
\text { of the new drug. }\end{array}$ & $(23,36)$ \\
\hline & Headroom analysis & $\begin{array}{l}\text { It is a QALY* approach that evaluates emerging technologies by } \\
\text { considering the maximum potential of the effect of technology, the } \\
\text { maximum willingness to pay (WTP) for this EFFECT, and de- } \\
\text { creases the potential costs involved in applying this technology. }\end{array}$ & $(27,31,40,45)$ \\
\hline & Expert elicitation & $\begin{array}{l}\text { It is a method to measure unknown parameters for evaluating a } \\
\text { new technology at the early stage of development from the ex- } \\
\text { perts' point of view. }\end{array}$ & $(45,43,38,34)$ \\
\hline & Scenario analyzing & $\begin{array}{l}\text { In this technique, a team of experts and analysts delineate the path } \\
\text { and dissemination of technologies across multiple scenarios and } \\
\text { then monitor and predict these technologies using specific criteria } \\
\text { such as efficiency, logistics, ethical/legal aspects, patient cen- } \\
\text { teredness and cost-effectiveness at the early stage of development. }\end{array}$ & $(26,38,42)$ \\
\hline & $\begin{array}{l}\text { Engineering risk } \\
\text { analysis }\end{array}$ & $\begin{array}{l}\text { This technique assesses the risk of failure by evaluating new tech- } \\
\text { nology compared to existing alternatives, and this method ulti- } \\
\text { mately depends on the decision maker's preferences and his degree } \\
\text { of risk taking. }\end{array}$ & (49) \\
\hline & MCDA & $\begin{array}{l}\text { In these methods, several options are compared against multiple } \\
\text { criteria; the best option or the most appropriate order of options } \\
\text { are selected. MADM methods, based on mathematical reasoning, } \\
\text { determine the best decision-making option out of the available } \\
\text { options by prioritizing them. }\end{array}$ & $(35,51)$ \\
\hline & Markov & $\begin{array}{l}\text { In this model, disease states are used to represent all the possible } \\
\text { consequences of an intervention. These models are fully exclusive. } \\
\text { So, every individual can be in just one disease state at any time. }\end{array}$ & $(44-46,52)$ \\
\hline & System dynamic & $\begin{array}{l}\text { Dynamic modeling is a simulation of the real world that is pre- } \\
\text { sented in mathematical terms with nonlinear relationships of the } \\
\text { real world. }\end{array}$ & $(5,15,22)$ \\
\hline
\end{tabular}




\begin{tabular}{|c|c|c|c|}
\hline Modelling & Technic & Definition & Study \\
\hline \multirow{3}{*}{ Pro-HTA } & Agent base model & $\begin{array}{l}\text { This model performs simulation simultaneously at three levels of } \\
\text { people, organization, and community. In this model, people are } \\
\text { called agents and can have individual characteristics as well as } \\
\text { dynamic behavior. }\end{array}$ & $(5)$ \\
\hline & $\begin{array}{l}\text { Clinical trial simula- } \\
\text { tion (CTS): }\end{array}$ & $\begin{array}{l}\text { This model uses mathematical synthesis to integrate simultaneous- } \\
\text { ly models of pharmacokinetics and pharmacodynamics drug ac- } \\
\text { tion, disease progression, placebo effects, and patient variability. }\end{array}$ & $(57)$ \\
\hline & $\begin{array}{l}\text { Best \& worse scal- } \\
\quad \text { ing }\end{array}$ & $\begin{array}{l}\text { Having chosen the list of objects, the researcher presents choice } \\
\text { sets of these to respondents to get the best and worst option data. }\end{array}$ & $(57)$ \\
\hline Priority setting & conjoint-analysis & $\begin{array}{l}\text { This is a survey-based statistical method used in market rese:arch. } \\
\text { In fact, this technique is based on evaluating people's preferences } \\
\text { of technologies based on specific criteria such as potential bene- } \\
\text { fits, processes, organizational aspects. }\end{array}$ & $(48)$ \\
\hline \multirow[b]{2}{*}{ Horizon scanning } & Delphi & The insights of experts are combined on a given question. & $(53)$ \\
\hline & MCDA & This method is described in the early HTA approach. & $(54)$ \\
\hline \multirow{2}{*}{ Forecasting } & Road mapping & $\begin{array}{l}\text { This method assesses potential opportunities and threats for tech- } \\
\text { nology and market development during product development and } \\
\text { delivery. Road-mapping has great potential in technology devel- } \\
\text { opment strategies and provides companies with relevant infor- } \\
\text { mation about their manufacturing processes and tools. }\end{array}$ & (19) \\
\hline & $\begin{array}{l}\text { Discrete-event simu- } \\
\text { lation: }\end{array}$ & $\begin{array}{l}\text { Discrete event simulation can also be used to forecast the impact } \\
\text { of changes in patient flow, to examine resource needs (either in } \\
\text { staffing or in physical capacity), or to investigate the complex } \\
\text { relationships among the different model variables (for example, } \\
\text { rate of arrivals or rate of service). }\end{array}$ & $(60,61)$ \\
\hline
\end{tabular}

5- Forecasting: This method is often used for industry. It attempts to graphically illustrate the future relationship between services, status, and the developed and under developing market variables. Once the future status and the path of technology are clear, there will be appropriate and timely feedback to continue the process of product development (19).

\section{The perspective of the included studies}

Conventional HTA approaches are limited in the pro- cess of health care decision-making in integrating a variety of preferences and stakeholder's perspectives (20). In other words, patient and public involvement are more focused and are not able to identify and respond to all stakeholders. According to Daniel's ethical framework of 'accountability for reasonableness, all reasons and criteria for funding health care should be accessible to all stakeholders (21).

Therefore, with different stakeholders in the health system, in decision-making about new technologies, the

Table 3. Dimension and criteria extracted from studies on emerging technologies evaluation

\begin{tabular}{|c|c|c|}
\hline Dimension & Criteria & Refrence \\
\hline Patient relevant outcome & $\begin{array}{l}\text { Compliance, mortality, progression rate, control of symptoms, restoration or } \\
\text { preservation of functionality, QALY }{ }^{1} \text {, accessibility to the service, affordabil- } \\
\text { ity to the individual }\end{array}$ & $\begin{array}{l}(14),(29),(13),(35),(15), \\
(11) .(13),(57),(41), \\
(43),(58),(59),(11),(55)\end{array}$ \\
\hline Technology relevant outcome & $\begin{array}{l}\text { Materials, market access, compatibility with existing technology, market } \\
\text { share, off label use, efficiency, price, cost, marketing factor, need to extra } \\
\text { services }\end{array}$ & $\begin{array}{c}(5),(7),(27),(36)(9), \\
(9),(40),(33),(48),(15), \\
(1),(1),(26),(14),(45), \\
(47),(13),(57),(41), \\
(43),(58),(59),(18),(55)\end{array}$ \\
\hline Innovation level & Clinical novelty, nature of treatment, ease of use, training & (30), (49), (41) \\
\hline Socioeconomic impact & $\begin{array}{l}\text { Public health, budget impact, social production, } \mathrm{WTP}^{2} \text {, financial access, equi- } \\
\text { ty, threshold, patient's interest }\end{array}$ & $\begin{array}{l}(14),(30),(40),(35),(13), \\
(14),(41),(43),(11),(55)\end{array}$ \\
\hline Social outcome of health care & $\begin{array}{l}\text { Burden of disease, treatment effectiveness, net monetary benefit, severity of } \\
\text { illness, hazard ratio, access, lifesaving, impact on future generation, number } \\
\text { of preventions, number of treatments, safety (adverse event, tolerability, } \\
\text { interaction, contraindication) }\end{array}$ & $\begin{array}{l}(30),(7),(29),(9),(40), \\
(13),(35),(48),(15),(1), \\
(1),(11),(26),(14),(49), \\
\quad(47),(13),(41),(43), \\
(58),(59),(11),(55)\end{array}$ \\
\hline Population dynamic & Birth, death, immigration, number of patients & (5) \\
\hline environment & $\begin{array}{l}\text { Organizational consequences, ethical, legal, national policy relevance, need, } \\
\text { current treatment strategy, patient characteristics }\end{array}$ & $\begin{array}{c}(14),(45),(47),(41),(11), \\
(55)\end{array}$ \\
\hline Financing & Reimbursement, public and privet health insurance, pay for extra services & (5), (26), \\
\hline
\end{tabular}


views of different stakeholders must be considered at the same time and when there is agreement on access to new technology from a variety of perspectives, including health, insurance, industry and the public, a decision that helps products develop and are based on real community's demand and prevent waste of resources is helpful $(5,22$, 23).

To this end, today, newer approaches such as pro-HTA, early HTA, horizon scanning, priority setting are being tried by different stakeholders to evaluate new technologies using different technics. Among the studies investigated in the present study, 10 studies were conducted from the decision maker's perspective, 1 from the physician's perspective, 7 from the societal perspective, 9 from the stockholders' perspective, 6 from the industry perspective, and one from the patient's perspective.

\section{Criteria extracted from studies on emerging technol-} ogies evaluation

To evaluate emerging technologies in the studies under consideration, different criteria have been taken into account, depending on the study's perspective. In this study, we tried to classify these criteria into larger dimensions by examining and aggregating them (Table 3 ).

Among the studies reviewed, 26 studies examined healthcare outcome criteria, 12 studies examined patientrelevant outcome, 17 studies examined technology relevant criteria, 10 studies examined socioeconomic criteria, 6 studies examined innovation level, 8 studies examined population dynamic, 8 studies examined environmental variables, and 9 studies examined financing criteria in their evaluations of technologies.

The studies used different criteria in their evaluations, but most studies used criteria such as the cost of access to new technology, budget impact, the burden of disease, Willingness To Pay (WTP), safety, effectiveness, and availability. The least attention is paid to technology-level criteria.

\section{Discussion}

The limitations of health resources have led researchers to consider the clinical and economic implications of investing in new technologies. Health Technology Assessment is used as a tool to ensure the maximum health of the community and prevent the emergence of inefficient technologies. It helps to ensure that the new technology is good value for money as long as it is ready to enter the clinical practice. However, such calculations at the time of the introduction of new technology into the treatment process will not help to improve the monetary value of the technology by making changes to the new technology. To prevent the loss of R\&D investments for new technologies, developers have proposed to evaluate the economic and clinical impacts of technology at an early stage of development.

In this study, 38 studies were found to meet the inclusion criteria, which were then examined based on their different evaluation techniques and perspectives and the criteria for technology monitoring. Five general evaluation methods for monitoring technologies (pharmaceutical and non-pharmaceutical) in the early stages of development were found, including Pro-HTA, Early-HTA, forecasting, and HSS. These methods are performed at or before the early clinical trial. Since at this stage of technology development, scientific evidence is limited, expert elicitation techniques are used alongside the methods to complete the evidence.

The findings showed that pro-HTA, early HTA, and HSS models, in their evaluations, often take into account the various stakeholders in the health system. They develop technology when there is an agreement on deciding to introduce new technology in terms of health, insurance, industry, and people's perspective. So this method develops products that are based on the community's real demand and help prevent the waste of resources $(2,15,23)$.

Chronologically, the pro-HTA method seems more recent than the other methods. Because of the complexity and lengthy scenarios of investigating the effects of emerging technology, the dynamic simulation models used in the PRO-HTA method have become increasingly popular.

Most of the studies we considered used the early HTA method. The Pro HTA method, taking into account various influential criteria in terms of industry, health system, people, and insurance of access to technology, helps corporate managers and the health system make decisions while simulating the results of an emerging product to optimize or reject an innovative product to avoid inappropriate investments $(24,25)$.

The early HTA approach is principally based on the concept of HTA, and the main difference is at their starting point of analysis. The HTA method is assessed after the technology is completed and before entering the treatment process, while in the early HTA method, it performs analysis during the technology research and development stages. In other words, the HTA approach is based on the results of evidence-based studies, so it is possible to use HTA after the development or implementation of new technology, while the early HTA evaluates technology at the early stage of product development. HSS also prioritizes new developing technologies.

Hartz et al. (2008) conducted the first systematic review in 2008 to identify methods for evaluating technologies at an early stage of development, which was in line with the purpose of the present study. It included 56 studies on pharmaceutical technology assessment and 27 studies on medical devices. In the present study, there were 7 studies on pharmaceutical products, 24 studies on medical devices, and 7 studies on evaluating both technologies.

Retele et al. (2009) studied the methods and results of nanotechnology evaluation in cancer care in the early stages of development and in the process of their diffusion. They found that most studies focused on the regulatory and safety (environmental) aspects and did not provide any structural assessment of dynamics, health economics, or organizational aspects (26).

Katarzyna Markiewicz (2014), in a study from 1996 to 2013, identified different techniques in technology assessment and evaluation. Compared to Hartz's study, they focused on medical devices and identified some qualita- 
tive and quantitative methods emphasizing that these techniques must be implemented before the product can be fully developed (27).

Maarten J. Ijzerman et al. identified 10 methods for assessing medical technologies at an early phase before market launch. They named them early HTA methods, while some of these techniques did not follow the principles of early HTA, which had been defined by Pietzsch and Pat'e-Cornell (2008). They defined early HTA on the principles of economic evaluation in the health economics discipline. In this definition, early HTA assesses the safety, effectiveness and cost-effectiveness of new medical technology (28). But MCDA or Horizon scanning techniques are developed to trace new technologies for broader dimensions previously defined for early HTA. MCDA captures some criteria in addition to safety, clinical effectiveness and cost-effectiveness of new technology such as the severity of disease, size of targeted population and equity consideration $(29,30)$. Horizon scanning not only focused on potential safety, clinical effectiveness and economic impact of emerging technologies but also considered other impacts of emerging technologies. To deal with the above reasons, we revisited the classification for methods in the previous study (28).

Claudia Wild et al. also conducted a systematic review to identify the countries using the HSS approach and its process and practice. Finally, 13 countries were identified that studied the same processes such as identification and filtering, prioritization, initial evaluation, diffusion, and monitoring of the technologies evaluated.

It is noteworthy that studies evaluating pharmaceutical products date back to 2000 and earlier. In recent years this assessment has shifted to medical devices. It could be due to shorter clinical trial lengths for medical devices compared to medicines and, as a result, easier appraisal and estimation of outcomes, the shorter life cycle of equipment, more predictable outcomes in product development compared to pharmaceutical products, more expensive equipment in most cases and consequent costs of technology (repairs, maintenance).

In the future, the use of early technology evaluation strategies such as Early HTA and pro-HTA will be more desirable given the constraints emerging from limited resources, increased demand, complex dynamics of disease, increased pressure on health systems, and increased uncertainty in $R \& D$ on the production of medical services. It is expected that the results of these studies will lead to value-dependent pricing.

This study faced some limitations. The timeframe of the present study was limited to studies that were published since 2000 . We did not fully search grey literature to find relevant studies. We might have missed some studies which would be potentially included. However, systematic review studies indicate that a specific method to measure the economic and clinical impact of emerging technologies at the development stage has not been eliminated.

\section{Conclusion}

Given the limited financial resources of the health sector in most countries, to invest in the R\&D sector in the de- velopment of emerging medical technologies, research should ensure that technology can be incorporated into the therapeutic process. Different methods were used to investigate the impacts of emerging medical technologies. Chronologically Pro-HTA methods are new ways for investigating emerging medical technologies beyond clinical and economic impacts. Assessing the feasibility of implementing Pro-HTA in real environments requires further research.

\section{Conflict of Interests}

The authors declare that they have no competing interests.

\section{References}

1. Angelis A, Kanavos P. Multiple criteria decision analysis (MCDA) for evaluating new medicines in health technology assessment and beyond: the advance value framevwork. Soc Sci Med. 2017 Sep $1 ; 188: 137-56$.

2. Djanatliev A, Kolominsky-Rabas P, Hofmann BM, Aisenbrey A, German R. System dynamics and agent-based simulation for prospective health technology assessments. In Simulation and Modeling Methodologies, Technologies and Applications 2014 (pp. 85-96). Springer, Cham.

3. Altman SH, Blendon R. Medical Technology: The Culprit Behind Health Care Costs?: Proceedings of the 1977 Sun Valley Forum on National Health. US Department of Health, Education, and Welfare, Public Health Service, Office of Health Research, Statistics, and Technology, National Center for Health Services Research, Health Resources Administration, Bureau of Health Planning; 1979.

4. Neumann PJ, Weinstein MC. The diffusion of new technology: costs and benefits to health care. Chang Econ Med Technol. 1991;2:21-34.

5. Kolominsky-Rabas PL, Djanatliev A, Wahlster P, Gantner-Bär M, Hofmann B, German R, et al. Technology foresight for medical device development through hybrid simulation: The ProHTA Project. Technol Forecast Soc Change. 2015 Aug 1;97:105-14.

6. Daudt HM, van Mossel C, Scott SJ. Enhancing the scoping study methodology: a large, inter-professional team's experience with Arksey and O'Malley's framework. BMC Med Res Methodol. 2013;13(1):48.

7. Clemens K, Garrison LP, Jones A, Macdonald F. Strategic use of pharmacoeconomic research in early drug development and global pricing. Pharmacoeconomics. 1993 Nov;4(5):315-22.

8. Mauskopf J, Schulman K, Bell L, Glick H. A strategy for collecting pharmacoeconomic data during phase II/III clinical trials. Pharmacoeconomics. 1996 Mar;9(3):264-77.

9. Grabowski H. The effect of pharmacoeconomics on company research and development decisions. Pharmacoeconomics. 1997;11(5):389397.

10. Terrés CR. Pharmacoeconomic analysis in new drug development: a pragmatic approach to efficiency studies. Clin Res Regul Aff. 1998;15(3-4):209-223.

11. Annemans L, Genesté B, Jolain B. Early modelling for assessing health and economic outcomes of drug therapy. Value Health. 2000;3(6):427-434

12. Dong H, Boxton M. Early assessment of the likely cost-effectiveness of a new technology: a Markov model with probabilistic sensitivity analysis of computer-assisted total knee replacement. Int $\mathrm{J}$ Technol Assess Health Care. 2006;22(2):191 -202.

13. Van Til JA, Renzenbrink GJ, Groothuis K, Ijzerman MJ. A preliminary economic evaluation of percutaneous neuromuscular electrical stimulation in the treatment of hemiplegic shoulder pain. Disabil Rehabil. 2006 Jan 1;28(10):645-51.

14. Hjelmgren J, Ghatnekar O, Reinner J, Grabowski M, Lindvall O, Persson U, et al. Estimating the value of novel interventions for Parkinson's disease: an early decision-making model with application to dopamine cell replacement. Parkinsonism Relat Disord. 2006;12(7):443-452.

15. Kolominsky-Rabas PL, Djanatliev A, Wahlster P, Gantner-Bär M, Hofmann B, German R, et al. Technology foresight for medical device development through hybrid simulation: The ProHTA Project. Tech- 
nol Forecast Soc Change. 2015 Aug 1;97:105-14.

16. Joppi R, Demattè L, Menti AM, Pase D, Poggiani C, Mezzalira L. The Italian horizon scanning project. Eur J Clin Pharmacol. 2009 Aug;65(8):775-81.

17. Hutubessy R, Chisholm D, Edejer TT. Generalized costeffectiveness analysis for national-level priority-setting in the health sector. Cost Effect Resource Alloc. 2003;1(1):8.

18. Chalkidou K, Glassman A, Marten R, Vega J, Teerawattananon Y, Tritasavit N, et al. Priority-setting for achieving universal health coverage. Bullet World Health Organiz. 2016 Jun 1;94(6):462.

19. Phaal R, Farrukh CJ, Probert DR. Technology roadmapping-A planning framework for evolution and revolution. Technol Forecast Soc Change. 2004 Jan 1;71(1-2):5-26.

20. Wahlster P, Goetghebeur M, Schaller S, Kriza C, Kolominsky-Rabas P. Exploring the perspectives and preferences for HTA across German healthcare stakeholders using a multi-criteria assessment of a pulmonary heart sensor as a case study. Health res policy syst. 2015 Dec;13(1):1-1.

21. Jansen MP, Baltussen R, Bærøe K. Stakeholder participation for legitimate priority setting: a checklist. Int J Health Policy Manag. 2018;7(11):973

22. Djanatliev A, German R. Prospective healthcare decision-making by combined system dynamics, discrete-event and agent-based simulation. in Proceedings of the 2013 Winter Simulation Conference: Simulation: Making Decisions in a Complex World. 2013. IEEE Press

23. Gantner-Bär M, Meier F, Kolominsky-Rabas P, Djanatliev A, Metzger A, Voigt W, et al. Prospective Assessment of an innovative test for prostate cancer screening using the VITA process model framework. InMIE 2014 Jan 1 (pp. 236-240).

24. Djanatliev A, German R. Prospective healthcare decision-making by combined system dynamics, discrete-event and agent-based simulation. In2013 Winter Simulations Conference (WSC) 2013 Dec 8 (pp. 270-281). IEEE

25. Chahal K, Eldabi T. Applicability of hybrid simulation to different modes of governance in UK healthcare. In 2008 Winter Simulation Conference 2008 Dec 7 (pp. 1469-1477). IEEE.

26. Retèl VP, Joore MA, Linn SC, Rutgers EJ, van Harten WH. Scenario drafting to anticipate future developments in technology assessment. BMC Res Notes. 2012 Dec;5(1):1-2.

27. Markiewicz K, van Til JA, Steuten LM, IJzerman MJ. Commercial viability of medical devices using Headroom and return on investment calculation. Technol Forecast Soc Change. 2016 Nov 1;112:338-46.

28. Ijzerman MJ, Steuten LM. Early assessment of medical technologies to inform product development and market access. Appl Health Econ Health Policy. 2011;9(5):331-347

29. Nouhi M, Hadian M, Jahangiri R, Hakimzadeh M, Gray S, Olyaeemanesh A. The economic consequences of practice style variation in providing medical interventions: A systematic review of the literature. J Educ Health Prom. 2019;8.

30. Baltussen R, Marsh K, Thokala P, Diaby V, Castro H, Cleemput I, et al. Multicriteria decision analysis to support health technology assessment agencies: benefits, limitations, and the way forward. Value Health. 2019 Nov 1;22(11):1283-8.

31. van Nimwegen KJ, Lilford RJ, van der Wilt GJ, Grutters JP. Headroom beyond the quality-adjusted life-year: the case of complex pediatric neurology. Int J Technol Assess Health Care. 2017;33(1):5-10.

32. Angelis A, Kanavos P. Multiple criteria decision analysis (MCDA) for evaluating new medicines in health technology assessment and beyond: the Advance Value Framework. Soc Sci Med. 2017;188:137156.

33. Gupta A, Juneja S, Vitoria M, Habiyambere V, Nguimfack BD, Doherty M, et al. Projected uptake of new antiretroviral (ARV) medicines in adults in low-and middle-income countries: a forecast analysis 2015-2025. PloS One. 2016 Oct 13;11(10):e0164619.

34. Kip MM, Steuten LM, Koffijberg H, IJzerman MJ, Kusters R. Using expert elicitation to estimate the potential impact of improved diagnostic performance of laboratory tests: a case study on rapid discharge of suspected non-ST elevation myocardial infarction patients. J Evaluat Clin Pract. 2018 Feb;24(1):31-41.

35. Middelkamp HHT, van Der Meer AD, Hummel JM, Stamatialis DF, Mummery CL, Passier R, et al. Organs-on-chips in drug development: the importance of involving stakeholders in early health technology assessment. Appl In Vitro Toxicol. 2016;2(2):74-81.

36. Püntmann I, Schmacke N, Melander A, Lindberg G, Mühlbauer B.
EVITA: a tool for the early evaluation of pharmaceutical innovations with regard to therapeutic advantage. BMC Clin Pharmacol. 2010 Dec;10(1):1-1

37. Fermont JM, Douw KH, Vondeling H, IJzerman MJ. Ranking medical innovations according to perceiived health benefit. Health Policy Technol. 2016 Jun 1;5(2):156-65.

38. Joosten SE, Retèl VP, Coupé VM, van den Heuvel MM, Van Harten WH. Scenario drafting for early teichnology assessment of next generation sequencing in clinical oncology. BMC Cancer. 2016 Dec;16(1):1-0.

39. Huygens SA, Rutten-van Mölken MP, Bekkers JA, Bogers AJ, Bouten CV, Chamuleau SA, et al. Conceptual model for early health technology assessment of current and novel heart valve interventions. Open Heart. 2016 Oct 1;3(2):e000500.

40. Girling A, Lilford R, Cole A, Young T. Headroom approach to device development: Current and future directions. Int J Technol Assess Health Care. 2015;31(5):331-8.

41. de Windt TS, Sorel JC, Vonk LA, Kip MM, Ijzerman MJ, Saris DB. Early health economic modelling of single-stage cartilage repair. Guiding implementation of technollogies in regenerative medicine. J Tissue Engin Regenerat Med. 2017 lOct;11(10):2950-9.

42. Ruile G, Djanatliev A, Kriza C, Meier F, Leb I, Kalender WA, et al. National Leading-Edge Cluster Medical Technologies 'Medical Valley EMN'. Screening for breast cancer with Breast-CT in a ProHTA simulation. J Compar Effect Res. 2015 Nov;4(6):553-67.

43. Haakma W, Steuten LM, Bojke L, IJzerman MJ. Belief elicitation to populate health economic models of medical diagnostic devices in development. Appl Health Econ Health Policy. 2014 Jun;12(3):327-34.

44. Jönsson B. Bringing in health technology assessment and costeffectiveness considerations at an early stage of drug development. Mol Oncol. 2015;9(5):1025-1033.

45. Cao Q, Postmus D, Hillege HL, Buskens E. Probability elicitation to inform early health economic evaluations of new medical technologies: a case study in heart failure disease management. Value Health. 2013 Jun 1;16(4):529-35

46. Retèl VP, Grutters JP, van Harten WH, Joore MA. Value of research and value of development in early assessments of new medical technologies. Value Health. 2013 Jul 1;16(5):720-8.

47. Postmus D, de Graaf G, Hillege HL, Steyerberg EW, Buskens E. A method for the early health technology assessment of novel biomarker measurement in primary prevention programs. Stat Med. 2012 Oct $15 ; 31(23): 2733-44$

48Golan O, Hansen P, Kaplan G, Tall O. Health technology prioritization: which criteria for prioritizing new technologies and what are their relative weights? Health Policy. 2011 Oct 1;102(2-3):126-35.

49. Pietzsch JB, Paté-Cornell ME. Early technology assessment of new medical devices. Int J Technol Assess Health Care. 2008;24(1):36-44.

50. Cosh E, Girling A, Lilford R, McAteer H, Young T. Investing in new medical technologies: a decision framework. J Commerc Biotechnol. 2007 Aug;13(4):263-71.

51. Stang PE, Pham SV, Kinchen K, Raff SB, Mussen F, Gondek K. The identification of benefit in medical intervention: an overview and suggestions for process. Am J Ther. 2008 Sep 1;15(5):495-503.

52. Dong H, Buxton M. Early assessment of the likely cost-effectiveness of a new technology: a Markov model with probabilistic sensitivity analysis of computer-assisted total knee replacement. International $\mathrm{J}$ Technol Assess Health Care. 2006;22(2):191-202.

53. Douw K, Vondeling H. Selection of new health technologies for assessment aimed at informing decision making: A survey among horizon scanning systems. Int $\mathbb{J}$ Technol Assess Health Care. 2006;22(2):177-183

54. Douw K, Vondeling H, Oortwijn W. Priority setting for horizon scanning of new health technologies in Denmark: Views of health care stakeholders and health economists. Health Policy. 2006;76(3):334 345 .

55. Van Til JA, Renzenbrink GJ, Groothuis K, Ijzerman MJ. A preliminary economic evaluation of percutaneous neuromuscular electrical stimulation in the treatment of hemiplegic shoulder pain. Disabil Rehabil. 2006 Jan 1;28(10):645-51.

56. Hjelmgren J, Ghatnekar O, Reinner J, Grabowski M, Lindvall O, Persson U, et al. Estimating the value of novel interventions for Parkinson's disease: an early decision-making model with application to dopamine cell replacement. Parkinsonism Relat Disord. 2006 Oct $1 ; 12(7): 443-52$.

57. Miller P. Role of pharmacoeconomic analysis in R\&D decision 
making. Pharmacoeconomics. 2005;23(1):1-12.

58. Phaal R, Farrukh CJ, Probert DR. Technology roadmapping-a planning framework for evolution and revolution. Technol Forecast Soc Change. 2004;71(1-2):5-26.

59. Douw K, Vondeling H, Sørensen J, Jørgensen T, Sigmund H. "The future should not take us by surprise": Preparation of an early warning system in Denmark. Int J Technol Assess Health Care. 2004 Aug;20(3):342-50.

60. Kim WJ, Lee JD, Kim TY. Demand forecasting for multigenerational products combining discrete choice and dynamics of diffusion under technological trajectories. Technol Forecast Soc Change. 2005 Sep $1 ; 72(7): 825-49$.

61.DiMasi JA, Caglarcan E, Wood-Armany M. Emerging role of pharmacoeconomics in the research and development decision-making process. Pharmacoeconomics. 2001 Jul;19(7):753-66.

62. Annemans L, Genesté B, Jolain B. Early modelling for assessing health and economic outcomes of drug therapy. Value Health. 2000 Nov 1;3(6):427-34 
Appendix. Search strategy in Pubmed:

$\# 1$ simulat* $[\mathrm{T} / \mathrm{A}](536,040)$

$\# 2$ forecast $[\mathrm{T} / \mathrm{A}](8,918)$

\#3 forecasting [MeSH Subheading] $(388,878)$

\#4 forecasting [All Fields] $(652,477)$

\#5 future [All Fields] $(886,484)$

\#6 emerging assessment [All Fields] $(170,413)$

\#7 foresight process* [T/A] (303)

\#8 Technology Foresight [T/A] (717)

\#9 health technology assessment $[\mathrm{T} / \mathrm{A}](4,857)$

\#10 horizon scanning [T/A] (195)

\#11 pro HTA[All Fields] (45)

\#12 HTA [T/A] $(3,084)$

\#13 dynamic model [T/A] $(4,430)$

$\# 14$ prospective assessment [T/A] $(1,584)$

$\# 15$ trends [MeSH Subheading] $(388,787)$

\#16 prospective simulation [T/A] (36)

\#17 early assessment [T/A] $(2,445)$

\#18 assessment, biomedical technology [MeSH Terms] $(11,143)$

\#19 health technology [MeSH Terms] $(14,210)$

\#20 computer simulation [MeSH Subheading] $(238,945)$

\#21 (\#1 OR \#2 OR \#3 OR \#4 OR \#5 OR \#6 OR \#7 OR \#8 OR \#9 OR \#10 OR \#11 OR \#12 OR \#13 OR \#14 OR \#15 OR \#16 OR \#17 OR \#18 OR \#19

OR \#20) $(1,681,216)$

\#22 pharmaceutical innovation [T/A] (229)

\#23 pharmaceutical diffusion [T/A] $(23,207)$

\#24 health technology diffusion [T/A] (4)

\#25 emerging diffusion [T/A] $(7,029)$

\#26 emerging drug [T/A] (795)

\#27 new drug [T/A] $(17,173)$

\#28 new medicine $[\mathrm{T} / \mathrm{A}](460)$

$\# 29$ drug entity [T/A] (85)

\#30 medicine entity $[\mathrm{T} / \mathrm{A}](22,869)$

\#31 emerging health technology [T/A] (12)

\#32 healthcare innovation [T/A] (25)

\#33 medical device* [T/A] $(15,393)$

\#34 innovation diffusion [MeSH Subheading] $(19,985)$

\#35 approval, new device [MeSH Subheading] $(2,944)$

\#36 approval, new drug [MeSH Subheading] $(15,530)$

\#37 (\#24 OR \#25 OR \#26 OR \#27 OR \#28 OR \#29 OR \#30 OR \#31 OR \#32 OR \#33 OR \#34 OR \#35 OR \#36) $(76,894)$

\#38 ("2000/01/01"[Date - Completion]: "2020/08/30"[Date - Completion]) $(17,885,956)$

\#39 (\#23 AND \#39 \#40) $(11,417)$ 